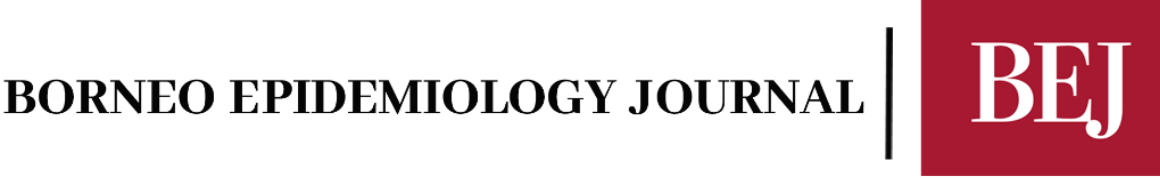

\section{Public Health Response to Restore Polio Free Status in Malaysia}

\author{
Richard Avoi ${ }^{1, *}$, Syed Sharizman Syed Abdul Rahim ${ }^{1}$, Pasupuleti Visweswara Rao ${ }^{2}$ \\ ${ }^{1}$ Department of Community and Family Medicine, Faculty of Medicine and Health Sciences, \\ Universiti Malaysia Sabah, Kota Kinabalu, 88400, Sabah, Malaysia \\ ${ }^{2}$ Department of Biomedical Sciences and Therapeutics, Faculty of Medicine and Health \\ Sciences, Universiti Malaysia Sabah, Kota Kinabalu, 88400, Sabah, Malaysia \\ Corresponding author:*richard.avoi@ums.edu.my
}

Received: 11/12/2020

Accepted: 17/12/2020

Malaysia started the polio immunization programme since 1972 and achieved polio-free certification in 2000. After 27 years from the last reported polio case in 1992, on 8 December 2019, the Ministry of Health Malaysia announced the return of polio into the country when the first polio case detected in Sabah involving a 3-month-old male child (Abdullah, N.H., 2019). The child confirmed to be infected with vaccine-derived poliovirus type 1 (VDPV1) which later classified as a circulating vaccine-derived poliovirus type 1 (cVDPV1). Further test confirmed that the virus is genetically linked to poliovirus (PHL-NCR-2) circulating in the southern Philippines (Alleman, M.M. et al., 2020). To date, a total of four polio cases were confirmed in Sabah of which due to vaccine-derived poliovirus type 1 (VDPV1). The vaccine-derived poliovirus type 2 (VDPV2) was also detected from environmental samples taken from various locations in Sabah.

In the neighboring countries, the Philippines and Indonesia also reported resurgence of polio after more than a decade free from the virus. Indonesia declared polio outbreak in February 2019 followed by the Philippines in September in the same year. Indonesia affected by the circulating vaccine-derived poliovirus type 1 and the Philippines affected by both circulating vaccine-derived poliovirus type 1 (cVDPV1) and circulating vaccine-derived poliovirus type 2 (cVDPV2) (Alleman, M.M. et al., 2020). To date a total of 15 cases have been reported in the Philippines.

In response to the polio outbreak, Malaysia embarked on an aggressive immunization drive to prevent the virus from spreading further. Similar move was also carried out in Philippines and Indonesia. Malaysia received a good support from the World Health Organization (WHO) and United Nations Children's Emergency Fund (UNICEF) in responding to this outbreak by ensuring all children under 13 years in Sabah receive the full doses of polio vaccine. 
With the supply of 2.5 million doses of monovalent oral polio vaccine type 2 (mOPV2) received from WHO and additional allocation from the Government of Malaysia for bivalent oral polio vaccine type 1 and 3 (bOPV), aggressive immunization campaign was conducted since December 2019 to children aged 13 and below across Sabah.

It is a known fact that the only effective way to eradicate polio is by protecting the children from polio through vaccination. The occurrence of polio cases in Sabah indicates that the population is under-immunized. About one-third of Sabah population is immigrant and it is a well-known fact that large number of them is illegal thus has lower immunization coverage. Therefore, the priority is to stop the polio transmission by making sure that every child, regardless of their economic and nationality status to have access to polio immunization. All children aged 13 years old and below should receive two doses of mOPV2 and two doses of bOPV, even those who have received inactivated polio vaccine (IPV) according to the national immunization schedule. This immunization drive will only be considered successful if the immunization coverage achieves at least $95 \%$ on all children under the age of 13 years old for both mOPV2 and bOPV.

To ensure the smooth implementation of the immunization campaign, cooperation and collaboration between various agencies including the non-governmental organizations are crucial. During the campaign, the Ministry of Health Malaysia urges parents, childcare centers, kindergartens and school authorities to help ensure that the children receive both vaccines. The Sabah State Health Department together with various government agencies and non-governmental organizations had work hand in hand to ensure the success of the campaign. The vaccination campaigns were conducted by mobile teams and also at government clinics, community halls, business centers, religious sites, and more including drive-thru services in strategic locations.

In addition to aggressive immunization campaign, equally important in public health response to this outbreak are intensified polio case finding activities, conducting a comprehensive field investigation which include a thorough risk assessment in order to properly plan an effective outbreak response. The acute flaccid paralysis (AFP) surveillance need to be strengthened by conducting retrospective and active searches for additional AFP cases at all health facilities across districts in Sabah.

The immunization campaign started well in early part of year 2020 until the COVID19 pandemic hit Malaysia. The first COVID-19 case was reported in Malaysia on 25 January 2020 and since then the cases continued to increase which prompt the Government of Malaysia to declared the movement control order (MCO) on 16 March 2020. The MCO interrupt badly the polio immunization drive. The campaign was only revived during the Recovery Movement Control Order (RMCO) that started in June 2020. With the COVID-19 cases recent surge in October 2020, the polio vaccination activities were halted again in many areas in Sabah. Despite all these obstacles, the immunization coverage as of 19 October 2020 was $95.6 \%$ children received two doses of bOPV and $80.6 \%$ for mOPV2 (Abdullah, N.H. 2020). As soon as the COVID-19 situation improve, vaccination activities for mOPV2 need to be continued until the target achieved for Malaysia to reclaims its polio-free status. 
The vaccine policy change in Malaysia from oral polio vaccine (OPV) to inactivated polio vaccine (IPV) was approved in 2008. The policy change is aimed to minimise the risk of outbreaks of vaccine-derived polioviruses. However, whenever there is an outbreak of vaccine-derived polioviruses, oral polio vaccine (OPV) which contains Sabin strain types 1, 2 and 3 continue to be used in response to the outbreak. To maintain the global eradication of wild poliovirus as well as VDPV will not be achieved if we continue to use the Sabin strain OPV in outbreak response. Thus new oral polio vaccines which are more stable genetically are needed. There are two novel OPV2 candidates currently under trial with promising result (Van, D.P. et al., 2020). The world is looking forward for better oral polio vaccines that will not result in VDPV emergence.

\section{References}

Abdullah, N.H.; Kenyataan Akhbar KPK 8 Disember 2019 -Kejadian Kes Polio Pertama Setelah Malaysia Diisytiharkan Bebas Polio - From the Desk of the Director-General of Health Malaysia [2019 December 8]. https://kpkesihatan.com/2019/12/08/kenyataan-akhbar-kpk-8-disember2019-kejadian-kes-polio-pertama-setelah-malaysia-diisytiharkan-bebas-polio/

Alleman, M.M., Jorba, J., Greene, S.A., Diop, O.M., Iber, J., Tallis, G., Goel, A., Wiesen, E., Wassilak, S.G.F, C. Burns, C.C. (2020). Update on Vaccine-Derived Poliovirus Outbreaks Worldwide, July 2019-February 2020. MMWR Morb Mortal Wkly Rep., 69(16):489-95. https://www.cdc.gov/mmwr/volumes/69/wr/mm6916a1.htm

Abdullah, N.H.; Kenyataan Akhbar KPK 24 Oktober 2020 - Sambutan Hari Polio Sedunia - From the Desk of the Director-General of Health Malaysia. [2020 October 24]. https://kpkesihatan.com/2020/10/24/kenyataan-akhbar-kpk-24-oktober-2020-sambutan-haripolio-sedunia/

Van, D.P., De, C.I., Bandyopadhyay, A.S., Revets, H., Withanage, K., De. S.P., Suykens, L., Steven, O.M., Weldon, C.W., Ann, C.C.S., Clemens, R., Modlin, J., Weiner, J.A., Macadam, J.A., Andino, R., Kew, M.O., Konopka, A.J.L., Burns, C.C., Konz, J., Wahid, R., Gast, C. (2020). The Safety and Immunogenicity of Two Novel Live Attenuated Monovalent (Serotype 2) Oral Poliovirus Vaccines in Healthy Adults: A Double-Blind, Single-Centre Phase 1 Study. Lancet, 394(10193), 148-158. https://www.thelancet.com/journals/lancet/article/PIIS01406736(19)31279-6/fulltext 